\title{
Robert Burns in Colonial Queensland: Sentiment, Scottishness and Universal Appeal
}

\author{
Patrick Buckridge
}

Worldwide, 25 January 2009 was celebrated as the 250th birthday of the great Scottish poet Robert Burns (1759-96). The anniversary celebrations will continue all through this year, however, as the Scottish Parliament has proclaimed - in recognition of Burns' powerfully unifying significance - that 2009 will be a 'Year of Homecoming' for all those Scots, or Scottish descendants, who compose the great intellectual, economic and social diaspora that has emanated from this tiny, harsh and indomitable country over the last 300 years.

The 'presence' of Burns in Australian history and culture is a large and complex topic, as well as an ongoing reality. This is the more so as that presence tends to differ in strength and character from one state to another - a consequence, in large part, of the distinct histories of Scottish immigration experienced by the several colonies that came together in 1901 to form the Commonwealth of Australia. Differences of religious denomination, of highland or lowland origins, of historical clan loyalties, alliances and enmities, even of language, all combined within the Scottish immigrant communities in different ways, and these communities themselves then developed differently, through the colonial period and beyond, in relation to the political culture, the religious and ethnic mix, and the economic conditions into which they came, and which - often from the beginning - they had helped to shape. These are not the sorts of questions that can be adequately addressed in a single paper, and I have not tried to do so.

My intention here is in fact fairly modest, though suitable enough to the time and place - Brisbane in 2009, the year of its own sesquicentenary and of Burns' sesqui-bicentenary (a word that not even Google recognises). It is simply to examine the presence of Burns in colonial Queensland. His most obvious public presence in Brisbane (leaving out of account his annual, largely unacknowledged appearance as the author of 'Auld Lang Syne') takes the form of a large statue, mounted on an even larger plinth, close to the centre of Brisbane. (There are Burns statues in several Australian towns and cities, and they are all very different from one another, so a comparative study is certainly there to be done.) 
The Brisbane statue (Figure 1) was completed in 1929 and erected, with some government assistance, by the Burns Club in 1932. The sculptor was Ward Willis. As can be seen, it closely resembles the better-known statue (Figure 2) erected in the little town of Paisley, just outside Glasgow, in 1896 by the sculptor F.W. Pomeroy, with the right hand on the plough and the broad-brimmed farmer's hat. The difference, I would suggest, is in Willis's allusion to Michelangelo's David in the posture of the Brisbane statue: this 'Michelangelisation' of the statue no doubt reflects the idealising and universalising character of the colonial appropriation of Burns, of which I shall have more to say in a moment.

The other fact of note about the Brisbane statue is that it occupies a public site, Centenary Place, which was opened in 1924 and envisaged as the forecourt of an enormous Catholic basilica, the Holy Name Cathedral, which fell victim to the Great Depression, so that only the foundations and the crypt were ever built. ${ }^{1}$ The lesson about the rewards due to Scottish prudence and Irish extravagance was probably not lost on Brisbane's Scottish community at least, though it may not have occurred to the Irish.

Comparison between the Scottish and Irish emigrations to nineteenth century Queensland does throw up some interesting sociological differences: for instance, whereas the large majority of the Irish arrivals in Queensland were working-class Catholics, the Scots migrants were much more uniformly distributed across the class spectrum. Families like the McConnels, Leslies, Mackenzies and McIlwraiths, for example, belonged to Queensland's pastoral and political elites, but there were also substantial numbers of Scottish merchants, tradesmen and labourers in the colony. ${ }^{2}$

Differences are also discernible between the Scottish and Irish literary immigrants. Hornibrook's bibliography of Queensland poetry indicates roughly equal numbers of Irish- and Scottish-born poets in the colony (about twenty of each) who were born before 1900, and published books of poetry in Queensland. ${ }^{3}$ Half of the Irish poets listed are women, but only one of the Scots poets. Whether that rather striking difference can be explained in terms of religious assumptions or cultural attitudes I am not sure - some features of Scotland's indigenous history and literature since the late sixteenth century do seem to suggest that a persistent and occasionally murderous misogyny has not been entirely alien to the Scottish soul in past centuries. The solitary Scotswoman was Mary Hannay Foott, née Black, who came to Melbourne from Glasgow at the age of seven in 1853 and moved to south-west Queensland with her husband in 1877. While living in the bush, she wrote her best-known poem (much anthologised in older collections of Australian verse), 'Where the Pelican Builds'. She later moved to Brisbane where she was the literary editor of the weekly newspaper The Queenslander for several years. ${ }^{4}$

A second difference between the Scots and the Irish literati has to do with the social and cultural prominence of the Scots: Scottish poets seem to have ruled the roost (such as it was) in Queensland in the nineteenth and early twentieth centuries. At least three of the best-known and most highly regarded poets in colonial Queensland were Scots. Two of them - Thomas Beaton Christie, known as 'Ralph Delany', and William Anderson Forbes, a.k.a. Alexander Forbes, a.k.a. 'Alick the Poet' - were the authors of, respectively, the first and second books of 


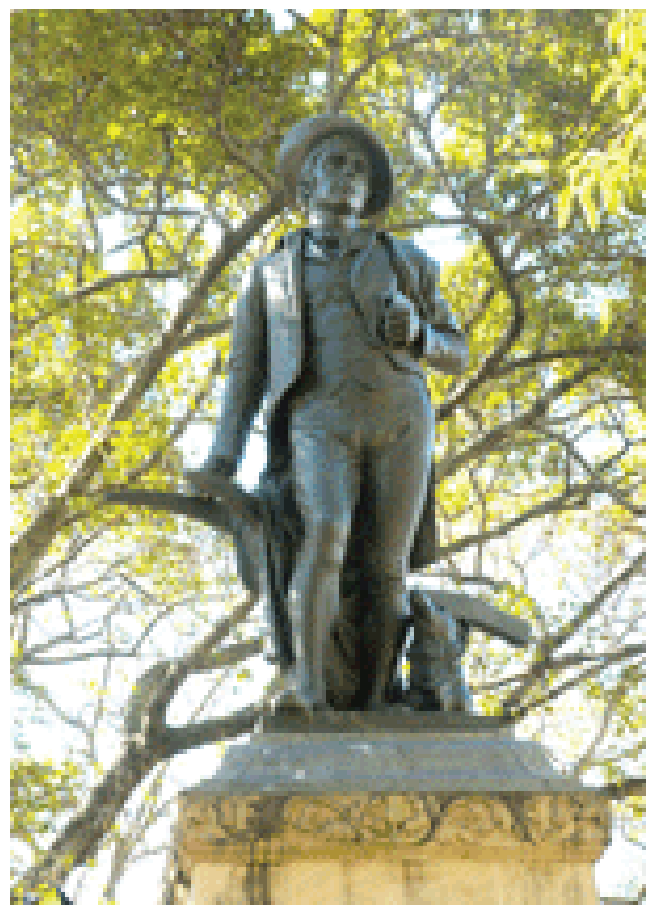

Figure 1: The Brisbane statue of Robert Burns in Centenary Place Source: (C) GlebeVista, all rights reserved.

Figure 2: The Burns statue by sculptor R.W. Pomeroy, in Paisley outside Glasgow.

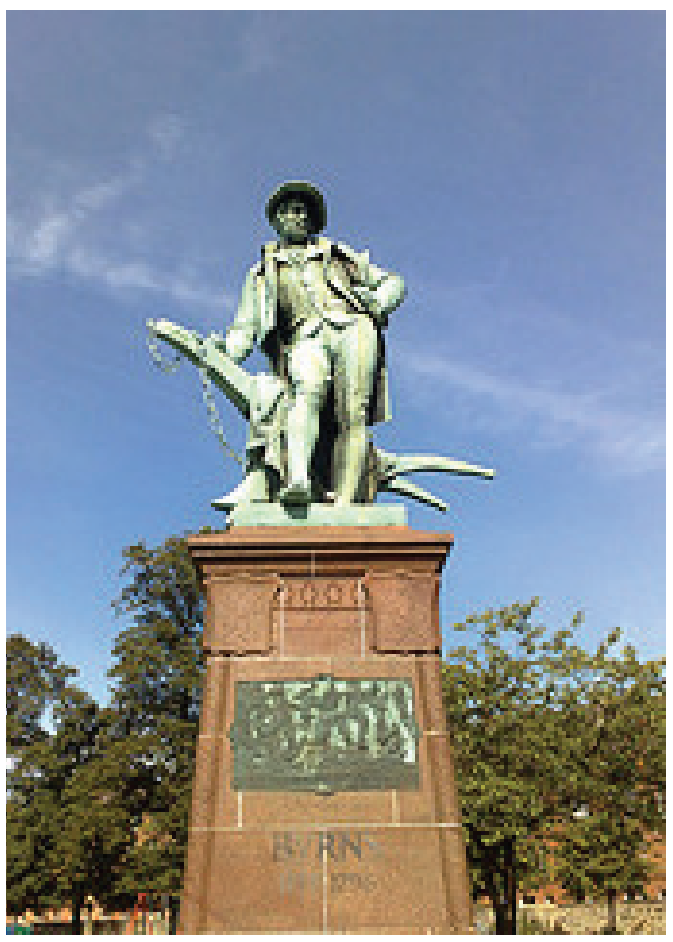

Vol. 16, No. 1, 2009 
verse printed in the colony, both in $1869 .{ }^{5}$ The third poet, James Brunton Stephens, was indisputably Queensland's premier poet for the last quarter of the nineteenth century: among much else, he was the author of a panegyric on Australian Federation, which was given semi-official national status in 1901; he was also known to generations of aspiring Queensland schoolchildren (myself included) in the 1960s as the eponymous sponsor of the Brunton Stephens Essay Prize in the Junior Public Examination at the end of Tenth Grade. ${ }^{6}$

Part of the reason why the Scottish poets shone so brightly in Queensland's literary firmament - during their lives, as well as after their deaths - is that some of them, at least, were well-connected to the social and political elites I mentioned earlier. Brunton Stephens, for example, was a protégé of Premier Thomas Mcllwraith, who rescued him from school teaching and placed him in the Colonial Secretary's Office; ${ }^{7}$ Thomas Christie (or Ralph Delany) had several of his poems set to music by Frank Leslie of the Darling Downs family; ${ }^{8}$ and William Burns of Maryborough, dedicated his Poetical Works (1881) to Alexander Leslie, of the Maryborough branch. ${ }^{9}$

Posthumous recognition helped as well. William Forbes' elder brother, the famous international war correspondent Sir Archibald Forbes, praised his 'poor shipwrecked brother' in a book of memoirs in 1885, six years after the latter's death at the age of 40; and the English anthologist Douglas Sladen, in 1891, praised the direct immediacy of his poetry. ${ }^{10}$ Most important of all, perhaps, was the extended and sympathetic treatment given to Stephens, Forbes and Christie by Henry Arthur Kellow, another Scot, in his justly admired critical study, The Queensland Poets, published in 1930. Kellow, a graduate of the University of Glasgow, moved to Queensland in 1912 to take up the post of Headmaster of Rockhampton Boys' Grammar. He was a pivotal figure in securing historical recognition for the Scottish contribution to early Queensland poetry, not only because of his own informed appreciations of the work of some of the immigrant-poets. He also helped to ensure the presence of classic Scottish writers like Burns and Scott in the school curriculum in the early decades of last century, both at his own school in Rockhampton and also throughout the Queensland secondary school system, with his book on Robert Burns in Harrap's 'Poetry and Life Series' (1918) and a widely adopted textbook on the study of literature, using many Scottish examples (1911). ${ }^{11}$

The third characteristic of the Scottish literary migration is the extent to which it was centred on a single canonical writer as its national touchstone. That writer was, of course, Robert Burns. There is nothing resembling the cult of Burns in the Irish migration, and nothing very like it in the English migration either, where Shakespeare is less ethnically marked than Burns, and more of a shared property across the English-speaking world. In a similar fashion, I think it is true to say that even Scott and Stevenson were read and admired as British rather than Scottish writers. Burns, however, was not for sharing, at least not in that 'de-ethnicised' way. But that he was shared in other ways, even beyond the community of ethnic Scots and their immediate descendants, is evident in many accounts of the social and cultural life of the colony. 
Indeed, it seems as if Burns' popularity existed in two forms, both of which were embodied in the two types of organisation that were established in Queensland in the 1850s: the Scottish or Caledonian Society (the name alternated over time) and the Burns Club. In Brisbane at least, both organisations prospered, but remained separate until the middle of last century, their relationship varying over the years from close co-operation to rivalry to occasional bursts of antagonism, probably owing to changing political and social affiliations in the Brisbane scene. The Scottish Society, like most ethnic associations, had a philanthropic focus: it was primarily concerned with 'taking care of its ain', and for that reason alone - its funds for allocation to needy Scots being limited - it tended to be ethnically exclusive and to concentrate its efforts on cultivating and nurturing Scottish professional and business networks. The Burns Club, by contrast, was renowned for its welcoming attitude to all comers, Scots and non-Scots alike, and of course for its more purely cultural range of interests: poetry, music and haggis. ${ }^{12}$

What was it about Burns that sustained that kind of appeal to all and sundry, and for so long? In the 1920s, the Rev. J. Scott MacDonald, a high school English teacher and the author of a weekly 'literary leader' in the Brisbane Courier, wrote several articles on Burns' poetry and reputation. In one of them he directly confronts the doubts many sympathetic non-Scots must sometimes have felt about Burns' alleged greatness as a poet, doubts which had recently been expressed by Sir Arthur Quiller-Couch, Professor of Poetry at Cambridge, who had confessed that 'with the best will in the world', he could never understand why the Scots had made Burns rather than Scott their presiding national genius. 'I do not find poetry of any high order in "Scots Wha Hae" or "A Man's a Man for a' that".' MacDonald's answer is interesting:

Burns in one song can make the human heart vibrate to its deepest core in a way that the collected works of Sir Walter can never do. Nowhere does deep answer to deep as in his two themes of love and home - love in its rapture or despair, home as a happy fireside ... for wife and weans, or desolated by the blasts of misfortune, or far sundered by dividing seas from a wandering race. ${ }^{13}$

MacDonald is 'on to something' interesting here, not just about Burns' poetry in general, but - by implication - about one of its major functions in a society like that of colonial Queensland. He suggests that its distinctive appeal rests on a directness and intensity of feeling in relation to those things in life about which for better or worse - most ordinary people do at times have deep feelings: home and family, separation and bereavement, male friendship, a good dinner party, political independence, war (the glory of it more than the horror), social injustice, sexual love - and animals. This is not the complete book of human life, but it is a large number of pages for one poet to be able to address with a corresponding range of intense and infectious feelings. Whether this was the quality that his own and later generations of Scottish readers most valued in Burns, I am unsure. But I think it is what a great many colonial Queenslanders mainly loved about him and not only the Scottish immigrants and descendants among them. 
What I am suggesting is that Burns was as popular as he was in colonial Queensland not simply because he represented 'hame' or a rollicking good time (though I'm sure the latter came into it, especially on New Year's Eve), but because his poems and songs acted as a means of broadening and intensifying the affective dimension in people's lives, as a kind of 'civilising' instrument in fact. And it was able to work in this way not because - or not only because - he was a Scottish poet, but because he was, in the non-pejorative eighteenth century sense of the word, a 'sentimental' poet.

But note the paradox. Although Burns wrote quite a lot of poetry in standard eighteenth century English, the 'classic' Burns poems - the ones that are always recited and sung at Burns Club celebrations - are of course the dialect poems: 'My Luve is Like a Red Red Rose', 'To a Mouse', 'To a Haggis', 'Scots Wha Hae', 'Ae Fond Kiss', 'Tam o' Shanter', 'The Cotter's Saturday Night', 'The Twa Dogs', 'Holy Willie's Prayer', and so on. The novelist Henry Mackenzie, Burns' Scottish mentor and admirer, acknowledged that even he had to use a Glossary for some of them! How could the powerfully affective appeal of his poetry in Queensland have survived its linguistic difficulty? The answer, I think, is that the dialect must have worked as a kind of smokescreen or masking device which allowed and encouraged people - especially men - to experience a range of feelings and emotions with a sensitivity and intensity which would usually be inhibited or repressed by the rational, professional and masculine norms of an economically competitive, business-dominated, politically cut-throat place like Brisbane in the late nineteenth century - and for that matter, mutatis mutandis, like the smaller towns to the north and west as well: Rockhampton, Bundaberg, Maryborough and Warwick, each of which was the home, or the home-base, of at least one Scottish-born published poet writing in dialect.

Ironically, that same harsh patriarchal rationalism - the very ethos that the Burnsian dialect poems and songs were helping to soften and mitigate - was itself partly a product of the strong and pervasive influence of Scottish Presbyterianism in the colony. The essayist Walter Murdoch - not a Queenslander, alas, but probably Australia's most popular and widely read Scottish-born writer - wrote an essay in the 1930s called 'The Scottish Twins,' in which he claimed that 'the only way to understand a Scot is to recognize that there are two Scotlands. One is the Scotland of poetry and romance [and the other is] the Scotland of the Glasgow merchant, the most prosaic of God's creatures. ${ }^{14}$ The Scottish twins cohabit boldly, according to the historian Malcolm Prentis, not only inside Scottish culture, but inside the souls of individual Scots as well, including the soul of Robert Burns himself. ${ }^{15}$ In these terms, Burns' poetry was providing a Scottish solution to a partly Scottish problem - the problem of colonial incivility. One of the twins was set to soften and civilise the other.

If this is a valid hypothesis about the way Burns' dialect poetry functioned in the colonial environment, then it helps to explain two further interesting features of the Scottish literary diaspora in Queensland. One is the surprisingly large quantity of dialect poetry that was published locally. I have discovered five colonial Queensland poets in the Oxley and Fryer Libraries - all of them locally 
published - who wrote a substantial amount of their poetry in dialect: Thomas Christie, William Forbes, William Burns, William Main and Archibald Brown. I am unable to say whether they all use the same dialect - but it is apparent even to a non-Scot that the density and opacity of the dialect varies from poet to poet, from poem to poem, and even within the same poem. Admittedly, these were all Scottish-born poets, and therefore the primary audience they envisaged for their work was probably also the Scottish-born; and certainly the social occasions they invoke in their poetry are often celebrations of shared ethnicity far from home:

For proudly we lo'e Scotland yet,

Though lang we've been awa'

Frae her wild shores and heather hills

Far frae her lowlands fine,

Australians though we live and dee,

We're Scotch 'for auld lang syne' (William Main, 'A Nicht at Hame') ${ }^{16}$

It is clear nonetheless that their poems, like those of Burns, reached a wider readership than that, one that was equally (if differently) appreciative of Scottish dialect poetry, and was responded to what we might think of as a call to the Scotsman within.

The other interesting feature of these poets is how closely most of them modelled their themes, verse forms and sense of a bardic role on Burns' example. Christie, Forbes and William Burns, all of whom had written some of their verses - both Scots and English - before emigrating, are very much of the 'School' of Burns: they acknowledge his authority and, like the master, they write love poems to unnamed lassies, and also to various lovely Besses, Maggies, Tinas, Nellies, Jeanies, Annies and Kates - even a Highland Mary! ${ }^{17}$ They write occasional poems, drinking songs, dream poems, animal poems, epistles to 'brother poets', battle poems, rousing calls to the 'working men', satiric attacks on Presbyterian narrow-mindedness and moral prejudice, poems 'to my mither', and quiet celebrations of domestic bliss like 'The Cotter's Saturday Night'. Sometimes the homage to Burns is explicit, as with Delany's 'Bonnie Tina Harley':

For sweetly Robin Burns has sung

The lass amang the barley,

She could na' be sae fair as thee

My bonnie Tina Harley (Ralph Delany, 'Bonnie Tina Harley’)18

Each of them also engaged quite vigorously, as Burns himself had done, with their own time and place. Christie, whose devotion to the tradition of Wallace, Bruce, Burns and Scott did not inhibit a fierce Empire loyalism, writes an adoring poetic tribute to 'Victoria's Sailor son', Prince Alfred, on the occasion of his visit to Brisbane in 1869, a number of emigrant's farewells and exile's laments, and two addresses to Ireland, praising the tradition of Sheridan, Grattan, O'Connell and Moore, but calling on the Irish to crush the Fenians of the 1867 rebellion. Interestingly, one of these poems is written in a good phonetic approximation of 
an Irish brogue. The effect, as always with Anglo-Irish before Synge and Lady Gregory, is demeaning and comical, quite unlike the emotional intensity he can achieve with the Scots dialect. Christie is by no means a bad poet, and one can forgive a lot of mediocrity for the Dickinsonian second line below:
Alas! It may not ever be -
Death's busy wi' me now;
I feel him coursing through my veins -
His sweat is on my brow (Delany, 'The Exile's Deathbed', 11. 25-8, p. 77)

Forbes and William Burns, both of them more republican in tendency than Christie, shared his general distaste for Queensland, and in particular for its heat, insects and lack of jobs. Forbes' attack (in plain English) on the lies of the migration-recruiters and the greed of the squatters (many of them Scottish) is deeply felt, but he recovered his spirits sufficiently to form a Glee Club, the Melodious Mullets, in the gold-mining town of Morinish, west of Rockampton, for which he became official bard. ${ }^{19}$ William Burns of Maryborough was similarly unimpressed with the place:

In Queensland's clime I pray ye hark,

There if perchance ye dae get wark,

Like slaves they'll work ye on tae dark;

An' yet complain;

And o'er your head they'll stand and bark,

Wi' cauld disdain.

I have focused here on a small group of Scottish-born Queensland poets who wrote in dialect as well as English. There were many more Scottish-born poets, in the colonial period and later, who never wrote in dialect. One was a prominent Queensland identity for entirely non-literary reasons. Frederick Charles Urquhart (1858-1935) spent some years as an inspector with the notoriously brutal Native Police in North Queensland. He subsequently became Queensland Commissioner of Police and played a key role in crushing the Red Flag Riots in Brisbane in 1919. ${ }^{20}$ Urquhart wrote coolly reflective narrative and lyric poems, which he published under the title Camp Canzonettes (1891). They deal mainly with his time in North Queensland, and include a disturbingly dispassionate account of a murder by Aborigines and of the killing expedition that he himself led by way of reprisal. His musings on the landscape of his adopted land are similarly dispassionate, eschewing the alienation of the exile in favour of a commonsense appreciation of both landscapes:

Pleasant are Austral's forest glades,

When the wattle is in bloom:

And pleasant is a far-off land,

The heather and the broom.

You can't say much fairer than that! 
Brunton Stephens never wrote in dialect either (except for a few lines of dialogue by a pair of Presbyterian exploiters in Polynesia), even though (unlike Mary Hannay Foot) he left Scotland as an adult. So little interest, it seems, did he have in retaining his Scottish heritage in an unmodified form that he became a founding member of the Johnsonian Club, evidently unmoved by Johnson's notorious contempt for the Scots. The Johnsonians went about their improving work in the colony in a different way, and it was to that broader civilising project - more directly ethical and educational than affective in character - that Stephens and other Scottish-Australian literati gave their allegiance, rather than the more emotionally centred 'Burnsian' project I have tried to describe, which seems to me to be quite different from the Johnsonian project, though perhaps it was complementary to it. ${ }^{21}$

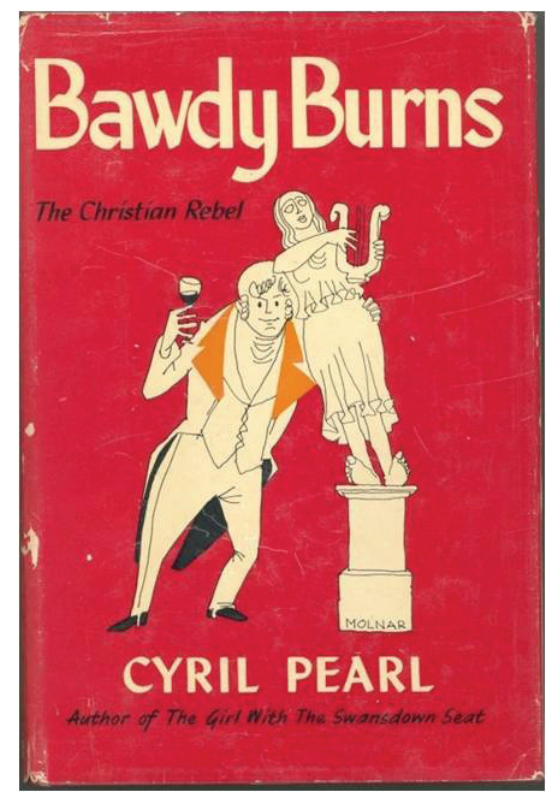

Figure 3: George Molnar's dust-jacket cartoon for Cyril Pearl's biography Bawdy Burns the Christian Rebel.

The 'Burns cult' itself changed its character in the mid-twentieth century, becoming, among other things, a focus for working-class politics in the interwar period, and an icon of religious and sexual libertarianism (particularly of the Sydney Push variety) in the 1950s - as in Cyril Pearl's biography Bawdy Burns: The Christian Rebel. ${ }^{22}$ George Molnar's dust-jacket cartoon for Pearl's book (Figure 3) provides a rather striking contrast to the icon with which this article began, the 'Michelangelised' statue of Burns in Centenary Place. Of this statue, I would want to suggest, by way of conclusion, that it somewhat misrepresents the real grounds of Burns' popularity with Queenslanders in the nineteenth and early twentieth centuries, because it implies a transcendence of Burns' Scottishness in the 
direction of a Renaissance ideal of youthful heroism. I would argue, to the contrary, that his deepest appeal for colonial Queenslanders rested on an intensification of his Scottishness, as conveyed through the affective power of his dialect poetry. It would be interesting to know whether the members of the Burns Club, which commissioned the statue, were happy with what they got.

\section{Notes}

1 T.P. Boland, James Duhig (St Lucia: University of Queensland Press, 1986), 230-35.

2 John Mackenzie-Smith, Moreton Bay Scots 1841-59 (Brisbane: Church Archivists' Press, 2000), $1-43$.

3 J.H. Hornibrook, Bibliography of Queensland Verse, with Biographical Notes (Brisbane: A.H. Tucker, Gov't Printer, 1953).

4 P. Buckridge and B. McKay, eds, By the Book: A History of Queensland (St Lucia: University of Queensland Press, 2006), pp. 37-38, 193-94.

5 Buckridge and McKay, By the Book, 17, 144. See also Cecil Hadgraft, Queensland and Its Writers (Brisbane: Queensland University Press, 1959), 2-4; and H.A. Kellow, The Queensland Poets (London: Harrap, 1930), 18-24, 32-35. (Kellow was unaware of the true identity of 'Ralph Delany,' a fact later uncovered by Hadgraft.)

6 Cecil Hadgraft, James Brunton Stephens (St Lucia: University of Queensland Press, 1969), $105-19$.

7 Hornibrook, Bibliography of Queensland Verse, 71.

8 Ralph Delany [T.B. Christie], Poems and Songs (Brisbane: A. Cleghorn, 1869), 7, 51, et al.

9 The Poetical Works of William Burns of Maryborough, Queensland (Maryborough: W.S. Lambert, 1885), Dedication.

10 R. Spencer-Browne, A Journalist's Memories (Brisbane: Read, 1927).

11 H.A. Kellow, Burns and his Poetry (London: Harrap, 1918); H.A. Kellow, A Practical Training in English (London: Harrap, 1911).

12 Leanne Day, 'Civilising the City: Literary Societies and Clubs in Brisbane during the 1880s and 1890s', PhD thesis, Griffith University, Brisbane (2004), 101-26.

13 J. Scott Macdonald, A Bookman's Essays (Sydney: Angus \& Robertson, 1928), 159.

14 Collected Essays of Walter Murdoch (Sydney: Angus \& Robertson, 1938), 432.

15 Malcolm Prentis, The Scots in Australia: A Study of New South Wales, Victoria and Queensland, 1788-1900 (Sydney: Sydney University Press, 1983), 194.

16 William Main, Bush Solitudes and Other Verses (Melbourne: George Robertson, 1896), 76.

17 'Highland Mary' was the name Burns gave to Mary Campbell (1763-86), with whom he had a relationship after separating from his wife-to-be Jean Armour. The relationship was terminated by her sudden death following a fever, and she is the subject of several of his love lyrics, notably 'The Highland Lassie, O'.

18 Delany [Christie], Poems and Songs, 45.

19 Alexander Forbes, Voices from the Bush (Rockhampton: Northern Argus, 1869), 57.

20 Raymond Evans, The Red Flag Riots: A Study of Intolerance (St Lucia: University of Queensland Press, 1988), 45-47.

21 For a full account of the Johnsonian Club in this period, see Leanne Day, 2003, "Those Ungodly Pressmen": A Study of the Early Years of the Brisbane Johnsonian Club', Australian Literary Studies 21.1 (2003): 92-102.

22 Cyril Pearl, Bawdy Burns: The Christian Rebel (London: Frederick Muller, 1958). 